\title{
Bracing for the Hidden Fallout: Systemic Implications of the Sino-US Trade Disputes at a Time of Changing International Trade Paradigms
}

\section{Jaemin Lee*}

Global trading regimes are currently undergoing significant changes. It is most vividly shown in the recent spread of FTAs and the surge of protectionism. These fast changes pose new challenges to many countries in terms of formulating and implementing their respective trade policies. The increasing confrontation between the United States and China in trade sectors now operates as a multiplier and accelerator of this fast-changing global trade landscape. Recent disputes between the two have underscored fundamental differences in understandings of the legal framework of the WTO Agreements and the nature of the obligations as Members, thereby further raising questions about the reinvigoration of multilateralism. The two countries' retaliatory initiation of trade disputes against each other also involves third countries because of legal requirements and other considerations. The Sino-US trade disputes are thus not merely confrontation between the two largest trading partners; instead they carry wider systemic implications for both other countries and global trading regimes in transition.

\section{Keywords}

Sino-US Trade Dispute, Doha Development Agenda, FTA, Trade Paradigm, WTO DSU.

* Professor of Law at Hanyang University School of Law, Korea. LL.B./LL.M./Ph.D.(SNU), J.D.(Boston College), LL.M.(Georgetown). The author may be contacted at: jaemin@hanyang.ac.kr / Address: School of Law, Hanyang University, 17 Haengdang-dong, Sungdong-gu, Seoul 133-791 Korea. 


\section{Introduction}

The United States and China are engaged in trade disputes on many fronts. ${ }^{1}$ Some of the disputes are pending at the dispute settlement proceedings of the World Trade Organization ("WTO”), while others are addressed bilaterally through respective domestic proceedings. Trade restriction measures adopted by the United States or China are readily counterweighted by comparable or similar measures by the other side. The vicious cycle of measures and countermeasures does not show any sign of slowing down at the moment and the growing consensus among trade watchers seems to be that this is just the beginning. In addition, more intense trade disputes, both quantitatively and qualitatively, are looming on the horizon on almost all trade fronts. ${ }^{2}$

The timing of the Sino-US disputes is particularly noteworthy. The bilateral disputes are taking place amid the changing paradigm of global trade. The multilateralism enshrined in the WTO regime is currently at a crossroads with the impasse of the Doha Development Agenda ("DDA"), while the WTO Members are actively pursuing various FTAs as an alternative. The surge of trade blocs and fragmentation of trade regimes are an ominous sign for the continuation and re-invigoration of multilateralism.

The increase of the Sino-US trade dispute combined with many regional trade agreements also poses new issues and difficult challenges for other countries in the world as it operates as a facilitator for the rapid fragmentation of the global trade regime. As the United States and China are usually the largest trading partners for many countries, it is not surprising that the trade friction between the two trade giants affects, for better or worse, the overall trade interests of other countries. If, however, the Sino-US bilateral disputes somehow create a new global trade environment in which these other countries are forced to encounter more disputes of their own and

1 See 2010 International Trade Update Proc, available at https://www.law.georgetown.edu/cle/pdfs/227.pdf (last visited on Mar. 1, 2013); M. Pettis, US-China Trade Relations - The Next Dispute?, Carnegie Endowment for International Peace, Feb. 17, 2010, available at http://www.carnegieendowment.org/publications/index. cfm?fa=view\&id=30975 (last visited on Mar. 1, 2013); A. Mason, US-China Trade Dispute Key Issue at G-20, CBS EVENING NEws, Sept. 24, 2009, available at http://www.cbsnews.com/8301-18563_162-5337960.html (last visited on Mar. 26, 2013).

2 Id. See also Ariana Eunjung Cha, US, China Locked in Trade Disputes, Wash. Post, Jan. 4, 2010, available at http://www.washingtonpost.com/wp-dyn/content/article/2010/01/03/AR2010010301961.html (last visited on Mar. 1, 2013). As for the increasing intensity of disputes between the United States and China through the WTO dispute settlement system and the relevant background, see C. Bown, US-China Trade Conflicts and Future of the WTO, 33 (1) Fletcher Forum World Aff. 28-32 (2009). 
to make more difficult policy choices, careful scrutiny is indeed necessary.

Keeping this in mind, the current research aims to discuss the "systemic implications' of US-China trade disputes for other countries. This paper consists of six parts including Introduction and Conclusion. Part two will discuss changing paradigms of global trade as a background to understanding the Sino-US bilateral trade dispute. Part three will examine the statistical data for Sino-US disputes to understand the intensity of the bilateral disputes. Part four will discuss the hidden systemic implications for other countries. Based on these discussions, Part five will look into possibilities of turning the bilateral disputes into an occasion for furthering key objectives of global trading regimes.

\section{A Shifting Paradigm in Global Trading Regime}

A paradigm change is being observed in the global trading regime, ${ }^{3}$ as the grip of multilateralism codified in the WTO Agreements has weakened over the years as a result of successive failure to conclude the DDA negotiations. The negotiations are now heading to the twelfth anniversary mark, but there is no sign of a final settlement. ${ }^{4}$ The apparent failure of the DDA has led to the rapid spread of FTAs and globally facilitated the surge of protectionism, particularly after the 2008 financial crisis.

\section{A. Accelerating Spread of FTA}

Today, the number of FTAs has significantly increased. As of January 2013, there are 354 FTAs in effect worldwide. ${ }^{5}$ It is reported that the United States and the European Union are close to sealing a free trade deal, ${ }^{6}$ an FTA that deserves particular attention

3 The WTO states that: "The ever-growing number of regional trade agreements and preferential trade arrangements is a prominent feature of international trade." See Regional Trade Agreements and Preferential Trade Agreements, WTO, available at http://www.wto.org/english/tratop_e/region_e/rta_pta_e.htm (last visited on Mar. 1, 2013).

4 WTO, Live Webcasting: Press Conference with Candidates, available at http://gaia.world-television.com/wto/2013/ dgsel_webcast_e.htm (last visited on Mar. 1, 2013).

5 As of January 10, 2013, the total number of notification of RTAs to WTO reached 546, among which 354 are in force. See WTO, Regional Trade Agreements, available at http://www.wto.org/english/tratop_e/region_e/region_ e.htm (last visited on Mar. 1, 2013).

6 C. Barfield, US-EU Free Trade in the State of Union, AEIdeas. (Feb. 13, 2013), available at http://www.aei-ideas. org/2013/02/us-eu-free-trade-in-the-state-of-the-union (last visited on Mar. 1, 2013). See also A. Walker, EU and US FreeTrade Talks Launched, BBC News, Feb. 13, 2013, available at http://www.bbc.co.uk/news/business-21439945 (last 
because it is a free trade pact between the two major trade players across the Atlantic. Arguably, none would be more damaging to the cause of the multilateralism than an FTA between these two blocs that have sustained multilateralism since the creation of WTO. The immediate tariff impact may not be that great, as their average tariff rates are already around three percent. What is important, however, are the implications for other countries. Two major economies, making up 30\% of global trade are closing in on an FTA, which is an important signal to other countries that the focus of trade regimes is shifting to bilateral trade agreements. In addition, on March 15, 2013, Japan also officially announced its plan to participate in the negotiation for the Trans-Pacific Partnership ("TPP”), a trans-Pacific free trade agreement sponsored and spearheaded by the US. Japan's latest announcement also carries a significant impact because it indicates that the country is shedding its traditionally cautious approach to FTAs and engaging in more active participation in the new trend. China, on the other hand, is also in the course of negotiating an FTA with Korea. All these developments will make those other countries currently sitting on the fence feel more pressure to jump on the band wagon so as not to be left out of this global trend. The landscape of global trade has thus overall changed. ${ }^{8}$

\section{B. Persistent and Creative Protectionism}

Ever since the global financial crisis in September 2008, protectionism has been apparent in many countries as an immediate alternative to revive sagging national economies. Protectionism is manifested in many different and creative forms in the WTO monitoring report on import restriction measures. ${ }^{9}$ Various Non-Tariff Barriers ("NTBs") have emerged, igniting an increasing number of international trade disputes. ${ }^{10}$ Some of these measures aim to achieve, on the surface, legitimate governmental objectives, such as environmental protection, public health enhancement, or consumer protection, but are in fact disguised trade restriction measures that have been adopted in order to circumvent otherwise applicable

visited on Mar. 1, 2013).

7 H. Tabuchi, Japan Moves to Enter Talks on Pacific Trade, N.Y. TIMES, Mar. 15, 2013, available at http://www. nytimes.com/2013/03/16/world/asia/japan-aims-to-join-trans-pacific-partnership-talks.html?pagewanted=all\&_r=0 (last visited on Mar. 15, 2013).

8 Against this backdrop, WTO remains vigilant for the spread of FTAs. See WTO, Regionalism: Friends or Rivals, available at $\mathrm{http}: / /$ www.wto.org/english/thewto_e/whatis_e/tif_e/bey1_e.htm (last visited Mar. 1, 2013).

9 See WTO Reports on Recent Trade Developments, available at http://www.wto.org/english/news_e/news12_e/ trdev_28nov12_e.htm (last visited on Mar. 1, 2013).

10 Asia Development Bank, How to Design, Negotiate and Implement a Free Trade Agreement in Asia 12 (2008), available at $\mathrm{http} / / / \mathrm{www} . a d b . o r g /$ sites/default/files/pub/2008/FTA.pdf (last visited on May 1, 2013). 
trade agreements. One of the recent examples is competitive currency devaluation adopted currently by multiple governments as an ultimate prescription to boost export and re-energize sagging domestic economies.

With the advent of protectionism and ensuing disputes over NTBs, the different perspectives of different countries have become equally apparent. Even between two closely related countries, respective understandings of trade related measures have sometimes been starkly different. For instance, the United States has been of the opinion that Korea maintains certain standards, technical regulations, and conformity assessment procedures that are burdensome and appear to have a disproportionate effect on imports. ${ }^{11}$ Korea, however, has disagreed with these US characterizations. ${ }^{12}$ The Korea-US FTA generally imposes tighter rules in a wide range of sectors than the WTO-based multilateral rules, so the allegations of NTBs and related disputes seem bound to surge in the near future, although both Korea and the United States have pledged to make efforts to implement various provisions domestically by enacting and amending laws and regulations. ${ }^{13}$ A similar situation is also observed between the United States and Japan in relation to the currency depreciation controversy and disputes. ${ }^{14}$

\section{The Sino-US Trade Disputes on the Rise}

\section{A. Overview of the Recent US-China Disputes at WTO}

The number of disputes between the United States and China at the WTO dispute settlement mechanism has rapidly increased since 2007. Since its accession to WTO in November 2001, China has experienced 43 disputes in total at the WTO dispute settlement mechanism as a direct party, either as a complainant or respondent. ${ }^{15}$

11 USTR, 2012 National Trade Estimate Report on Foreign Trade Barriers 246, available at http:/www.ustr.gov/sites/ default/files/NTE\%20Final\%20Printed_0.pdf (last visited on Apr. 17, 2013).

12 Jung-A Song, South Korea to Tighten Foreign Investment Rules, Financial Times, Dec. 28, 2007, available at http:// www.ft.com/intl/cms/s/0/3d0153ea-b4e6-11dc-990a-0000779fd2ac.html\#axzz2SPKPqHez (last visited on Mar. 1, 2013).

13 See Free Trade Agreement between the Republic of Korea and the United States of America (entered into force on Mar. 15, 2012) art. 23(2).

14 S. Bradford, An Analysis of a Possible Japan-US Free Trade Agreement [powerpoint presentation material] at slide nos. 16, 17, 20 \& 21, available at http://www.piie.com/publications/papers/bradford1107.pdf (last visited on Mar. 1, 2013).

15 WTO, Map of Disputes between WTO Members, available at http://www.wto.org/english/tratop_e/dispu_e/dispu_ 
Ever since the US and China encountered each other for the first time at a WTO panel proceeding in 2004, there have been 23 disputes between them; 17 disputes have been resolved, while six are still pending before the respective WTO dispute settlement proceedings. ${ }^{16}$ In fact, the six disputes currently under way make up the bulk of the disputes pending before the WTO panels and the Appellate Body. ${ }^{17}$ Major disputes that have been resolved are related to the IPR protection, ${ }^{18}$ trading rights and publication distribution network, ${ }^{19}$ tariff imposition for auto parts, ${ }^{20}$ raw materials export restraints, ${ }^{21}$ antidumping/countervailing duty simultaneous investigations, ${ }^{22}$ poultry import restriction dispute, ${ }^{23}$ and China-specific safeguards importation. ${ }^{24}$ All these resolved or pending US-China disputes have been raised since $2004 .^{25}$ Between November 2001 - when China joined $\mathrm{WTO}^{26}$ - and 2004, no disputes between the two countries were brought before WTO. ${ }^{27}$ In fact, the significance lies beyond just the numbers, as all US-China disputes have been high-profile ones in which many countries have displayed strong interest. ${ }^{28}$

At the same time, the United States and China are also active on the bilateral

maps_e.htm?country_selected=CHN\&sense=e (last visited on Mar. 1, 2013).

16 WTO, Chronological List of Dispute Cases, available at $\mathrm{http} / /$ www.wto.org/english/tratop_e/dispu_e/dispu_status_e.htm (last visited on Mar. 11, 2013).

17 As of March 14, 2013, 6 out of the 18 pending disputes are between the two countries. See id.

18 See China-Measures Affecting the Protection and Enforcement of Intellectual Property Rights (DS362) [hereinafter China-IPR], available at http://www.wto.org/english/tratop_e/dispu_e/cases_e/ds362_e.htm (last visited on Mar. 26, 2013).

19 See China-Measures Affecting Trading Rights and Distribution Services (DS363), available at http://www.wto.org/ english/tratop_e/dispu_e/cases_e/ds363_e.htm (last visited on Mar. 26, 2013).

20 See China-Measures Affecting Imports of Automobile Parts (DS339/340/342), available at http://www.wto.org/ english/tratop_e/dispu_e/cases_e/ds339_e.htm; http://www.wto.org/english/tratop_e/dispu_e/cases_e/ds340_e.htm; and http://www.wto.org/english/tratop_e/dispu_e/cases_e/ds342_e.htm (all last visited on Mar. 26, 2013).

21 See China-Measures Related to the Exportation of Various Raw Materials (DS394/395/398) [hereinafter China-Raw Materials], available at http://www.wto.org/english/tratop_e/dispu_e/cases_e/ds394_e.htm; http://www.wto.org/ english/tratop_e/dispu_e/cases_e/ds395_e.htm; and http://www.wto.org/english/tratop_e/dispu_e/cases_e/ds398_e.htm (all last visited on Mar. 26, 2013).

22 See United States-Definitive Antidumping and Countervailing Duties on Certain Products from China (DS379), available at http://www.wto.org/english/tratop_e/dispu_e/cases_e/ds379_e.htm (last visited on Mar. 26, 2013).

23 See United States-Measures Affecting Imports of Poultry from China (DS392), available at http://www.wto.org/ english/tratop_e/dispu_e/cases_e/ds392_e.htm (last visited on Mar. 26, 2013).

24 See United States-Measures Affecting Imports of Certain Passenger Vehicles and Light Truck Tyres from China (DS399), available at http://www.wto.org/english/tratop_e/dispu_e/cases_e/ds399_e.htm (last visited on Mar. 26, 2013).

25 Supra note 16.

26 WTO, Accession of the People's Republic of China, WT/L/432 (Nov. 23, 2001), available at http://www.worldtradelaw. net/misc/chinaaccessionprotocol.pdf (last visited on Mar. 26, 2013).

27 Supra note 16.

28 Disputes between the United States and China attract many third party participants because of their systemic implications. In China - Raw Materials, e.g., as many as 15 members participated as third parties. See WTO, DS394, supra note 21. 
front. China has been a perennial target of the US domestic trade remedy investigations, and the United States has recently become a frequent target of comparable Chinese investigations. It is indeed a new phenomenon that the US exporters are becoming frequent targets of trade remedy investigations by another country. This trend is also evidenced by statistics: in terms of antidumping investigations by the United States, during the period of July 2011 to June 2012, the most recent period for which the official WTO statistics are available, three out of five definitive antidumping duties were imposed by the United States against China, with Taiwan and Argentina following with one imposition, respectively. ${ }^{29}$ In comparison, during the same reporting period three out of six antidumping investigations initiated by China were lodged against the United States, which correspondingly placed the United States at the top of the China's target list. ${ }^{30}$ To understand the situation better, one needs to look into the historical data for antidumping investigations relating to the two countries. During the period of 1995 to 2012, the United States initiated 465 antidumping investigations in total, 109 of which were directed at Chinese products. ${ }^{31}$ It should be noted, however, that these antidumping investigations against China were mainly initiated after 2003 when Chinese products' penetration into the US market became evident after Beijing's accession to WTO in November 2001. In other words, if China had been a WTO Member throughout the entire reporting period of the statistics, one would see twice the reported number for the US antidumping investigations against China. From the Chinese side, during the same reporting period, 35 out of 195 antidumping investigations initiated by Beijing were directed at the American products, making the United States the most frequent target of China's investigations. ${ }^{32}$ Here again, it should also be borne in mind that the majority of the 35 investigations were initiated after 2006 when the bilateral tension flared up. If the disputes had persisted throughout the period, one would see a much higher number for Chinese investigations against the United States.

In terms of countervailing duty investigations, which are aimed at allegedly illegal subsidization policies of foreign governments, both instances of the US imposition of definitive countervailing duties between July 2011 and June 2012 were against China. ${ }^{33}$ During the same period, one of the two definitive countervailing

29 See WTO Report (2012) of the Committee on Antidumping Practices, G/L/1006 (Oct. 25, 2012), at 18.

$30 \quad I d$. at 16.

31 WTO, Antidumping Initiations: Reporting Member vs. Exporting Country, available at http://www.wto.org/english/ tratop_e/adp_e/AD_InitiationsRepMemVsExpCty.pdf (last visited on Mar. 1, 2013).

32 Id.

33 See WTO Report (2012) of the Committee on Subsidies and Countervailing Measures, G/L/1005, at 17 (Oct. 25, 2002). 
duties imposed by China was targeted at the United States. ${ }^{34}$ Yet again, more noteworthy is the historical record. Out of the 118 countervailing duty investigations in total initiated by the United States since 1995, 32 were lodged against China. ${ }^{35}$ This statistic should be digested against the backdrop that all these countervailing investigations against China have been initiated since 2006 when the United States decided to apply countervailing duties to China by revoking its traditional position not to impose them against Non-Market Economy ("NME") States. As this period takes up only one third of the total reporting period in the statistics, a mechanical conversion of the total instances for the 17-year period would reach almost 90 instances out of 112 instances. On the other hand, since China conducted its first countervailing duty investigation in 2008, three out of the four total investigations were initiated against US products. ${ }^{36}$ In short, on both the multilateral and bilateral fronts, the two countries seem to be engaged in full-blown trade battles.

In addition, there are other major US-China trade disputes that take place outside the WTO proceedings or the domestic trade remedy investigation context. Examples include Google's confrontation with the Chinese government regarding censorship of internet materials, ${ }^{37}$ which potentially implicates China's obligation to abide by its service market opening commitment under the General Agreement on Trade in Services ("GATS"), China's WTO Accession Protocol, ${ }^{38}$ and China's alleged depreciation of its currency to sustain its economy and exports, ${ }^{39}$ which potentially implicates the Agreement on Subsidies and Countervailing Measures (hereinafter SCM Agreement). ${ }^{40}$

\section{B. Unique Underpinnings of the Sino-US Disputes}

The US-China trade disputes are unique in the sense that they are more intense than

34 Id.

35 WTO, Countervailing Initiations: Reporting Member vs. Exporting Country, available at http://www.wto.org/english/ tratop_e/scm_e/CV_InitiationsRepMemVsExpCty.pdf (last visited on Mar. 1, 2013).

36 Id.

37 M. Helft \& D. Barboza, Google Shuts China Site in Dispute over Censorship, N.Y. TIMES, Mar. 22, 2010, available at http://www.nytimes.com/2010/03/23/technology/23google.html?_r=0 (last visited on Apr. 22, 2013).

38 Supra note 26.

39 H. Schneider, Obama Urged to Act on China's Currency Manipulation, WASH. Post, Mar. 26, 2010, available at http://www.washingtonpost.com/wp-dyn/content/article/2010/03/25/AR2010032503772.html (last visited on Mar. 1, 2013).

40 Supra note 11, at 61-95 (providing a summary of outstanding trade issues between the two countries as of March 31, 2012). 
any others under the WTO system. ${ }^{41}$ The uniqueness of US-China trade disputes arguably stems from the fundamental difference in perspectives between the two countries in terms of various trade-related economic and financial policies. The proper role of a sovereign government in response to demands from the market, ${ }^{42}$ permissible policy boundaries for a government to preserve key natural resources, ${ }^{43}$ appropriate administration of the criminal justice system of a government, ${ }^{44}$ and the outer parameters of foreign exchange policies ${ }^{45}$ are some examples of the issues that have been raised in recent US-China trade disputes. Obviously, these issues are far from being amenable to clear-cut solution by an international adjudicative body.

The text of a trade agreement rarely provides sufficient norms on these rather philosophical issues. Moreover, the understanding in the policy space flowing from provisions in the agreement largely depends on the perspectives of the parties to the agreement. ${ }^{46}$ In these circumstances, it is entirely possible that the disputing parties may have different opinions on the provisions, keeping good faith in mind that their respective positions are vindicated according to the textual language. ${ }^{47}$ They may simply have different perspectives in implementing national policies and carrying out obligations under a given trade agreement. The difference in perspectives is further amplified when there is interaction between trade norms codified in trade agreements and other international legal norms contained in non-trade international agreements. $^{48}$

41 In United States-Subsidies on Upland Cotton (WT/DS267/AB/R)/DSR 2005: I, 3 (Mar. 21, 2005), Brazil challenged the sensitive agricultural subsidies of the United States for its cotton industry. In Mexico-Measures Affecting Telecommunications Services (WT/DS204/R)/DSR 2004: IV, 1579 (Jun. 1, 2004), the United States challenged Mexico's discriminatory telecommunications policy for the benefit of a domestic carrier. For details on the disputes pending between the US and other countries, see supra note 16 .

42 One of the unique traits of Asian culture is for people to view the government in the context of carrying a paternal authority and role. This trait still remains and also appears in economic regulation. See Appellate Body Report, United States - Definitive Anti-Dumping and Countervailing Duties on Certain Products from China, WT/DS379/ AB/R, WTO (Mar. 25, 2011) [hereinafter US-AD/CVD (AB)].

43 See Appellate Body Report, China - Measures Related to the Exportation of Various Raw Materials, WT/DS394, 395, 398/AB/R (Feb. 22, 2012), available at http://www.wto.org/english/tratop_e/dispu_e/394_395_398abr_e.pdf (last visited on Mar. 26, 2013).

44 Panel Report, China - Measures Affecting the Protection and Enforcement of Intellectual Property Rights, WT/ DS362/R, (Mar. 29, 2009), available at http://www.wto.org/english/tratop_e/dispu_e/362r_e.doc (last visited on Mar. 26, 2013).

45 W. Morrison, China-US Trade Issues, CRS Report, at 14-15 (Jan. 7, 2011), available at http://fpc.state.gov/ documents/organization/155009.pdf (last visited on March 31, 2012).

46 M. Gordon \& C. Osakwe, Comparative Legal Traditions in a Nutshell 10 (1982).

47 Vienna Convention on the Law of Treaties art. 31. 1155 U.N.T.S. 331.

48 J. Lynn, Carbon Border Measures Seen Breaking WTO Trade Rules, ReuTERs, Dec. 3, 2009, available at http://www. reuters.com/article/idUSGEE5B22A1 (last visited on Mar. 1, 2013). 


\section{Hidden Implications of the Sino-US Disputes for Third Countries}

The bilateral disputes between the US and China have drawn significant attention, but the focus of such attention so far has usually been on the disputes themselves or the souring diplomatic relationship between the two. Rarely has there been a discussion about the systemic implication of the bilateral disputes in the broader context of the international trade regime at this time of paradigm shift and of perspectival division.

The systemic implications arising from the bilateral disputes therefore are not merely confined to the two countries, but significantly affect other third countries, as well. An accurate assessment of the global implications from the G-2 trade disputes would require that the disputes be put into perspective. These implications may include both negative and positive aspects. For instance, one of the positive aspects of increased disputes would be the enhancement of "rule of law" regarding the trade measures of these two countries. As Washington and Beijing are the largest trading partners for many countries, ${ }^{49}$ if the non-compliant measures of these two are identified and rectified as a result of the continuing two-way trade disputes, their respective trade partners, such as the EU, Japan and Korea, would enjoy incidental benefits. The fact that other countries may learn from the outcome of the intensifying Sino-US trade disputes in the course of formulating and adjusting their domestic trade policies would be another positive aspect in this respect. The contributions from the positive aspects could be minimal, however, if they are eclipsed by the negative implications. In the context of US-China trade disputes, it may well be the case given the breadth and depth of the negative implications. The negative implications to the other countries are summarized as follows: (1) other countries' being caught in the Sino-US trade disputes as collateral damage; (2) other countries' being torn between the two divergent frameworks of FTAs; and (3) other countries' being forced to choose between the different philosophical principles and approaches to economic policies.

49 See US-China Trade Statistics and China's World Trade Statistics, The US-China Business Council, available at http://www.uschina.org/statistics/tradetable.html (last visited on Mar. 1, 2013). 


\section{A. Falling into the Same Trap}

The first thing that needs to be examined in this respect is the increasing possibility that third countries are dragged into the bilateral disputes between the United States and China. This issue can be analyzed in terms of (1) trade remedy investigations, (2) other import restriction measures, and (3) manufacturing facilities re-location phenomenon.

\section{Trade Remedy Investigations}

An interesting development is taking place in the area of trade remedy investigations - such as antidumping investigations, and countervailing duty investigations conducted by the governmental agencies (called investigating authorities) of the United States and China. As the two countries seem to apply them as retaliatory countermeasures against trade remedy investigations carried out by the other, ${ }^{50}$ further countries and their companies become ensnared in these investigations. This is made possible because of the high level of discretion accorded to the domestic investigating authorities under the WTO Agreements. ${ }^{51}$ Indeed, when an investigating authority of a WTO Member has relied on a particular method for weighing the relevant evidence in a particular trade remedy investigation, a reviewing WTO panel is generally obliged to defer to the method thus chosen - an application of a deferential standard. ${ }^{52}$

Becoming a collateral victim in the cross-fire can occur in two different ways. One is when a product from a third country is dragged into an investigation by the US or China. A second possibility arises when the American or Chinese items produced within their territories from the factories established by investments from third countries become subject to an investigation by the other side. In the case of the United States, it is becoming more common that, in filing various Chinadirected petitions with the United States Department of Commerce ("USDOC");

50 It should be noted that countermeasures by a WTO Member is not prohibited to the extent that such countermeasures are adopted and applied in compliance with the relevant covered agreements. In US-Line Pipe, also in the context of the application of a safeguard, the Appellate Body emphasized the importance of the state responsibility rules which command the need for proportionality when imposing countermeasures. See Appellate Body Report, United States-Definitive Safeguard Measures on Imports of Circular Welded Carbon Quality Line Pipe from Korea, WT/ DS202/AB/R / DSR 2002:IV, 1403 (Mar. 8, 2002), at $\uparrow 259$.

51 See Appellate Body Report, Mexico-Definitive AntiDumping Measures on Beef and Rice, Complaint with Respect to Rice, WT/DS295/AB/R / DSR 2005:XXII, 10853 (Dec. 20, 2005), at ๆ 204, available at http://www.wto.org/english/ tratop_e/dispu_e/295abr_e.doc (last visited on Mar. 26, 2013).

52 See Appellate Body Report, United States-Countervailing Duty Investigation on Dynamic Random Access Memory Semiconductors ("DRAMS") from Korea, WT/DS296/AB/R / DSR 2005:XVI, 8131 (Jul. 20, 2005), available at http://www.wto.org/english/tratop_e/dispu_e/296abr_e.pdf (last visited on Mar. 26, 2013). 
the US investigating authority), domestic industries and corporations include other countries and their companies in the petitions as companion targets. ${ }^{53}$ While pieces of evidence and background information tend to indicate that the real motivation to file a petition is apparently directed against China, US domestic industries would bring other countries into the mix of the investigations. A similar phenomenon can also be shown in trade remedy petitions filed by Chinese domestic industries; it may be found in the investigations initiated by China's investigating authorities (Ministry of Commerce, "MOFCOM"). ${ }^{54}$ In fact, this is not merely coincidental, but there are specific strategic and legal reasons behind such broader inclusion.

This trend should be understood noting that the US and China are the two major utilizers of trade remedy investigations among the WTO Members. As of June 30, 2012, the United States holds a dominant first place in terms of antidumping investigations, having initiated 465 antidumping investigations against foreign exporters since the inception of WTO. ${ }^{55}$ With respect to countervailing duties, the United States has initiated 118 investigations during the same period and takes a solid first place in the list. ${ }^{56}$ What is noticeable, however, is that China is now emerging as a new frequent user of these trade remedy measures.

China has been a leading target of foreign antidumping investigations, with its trading partners having filed a total of 643 investigations against products exported from its territory. ${ }^{57}$ Given that Korea takes a distant second place with only 172 investigations against its products, ${ }^{58}$ the intensity of antidumping investigations by other countries against China is apparent. During the same period, China is also listed at the top of the countervailing duty target country list with the total of 37 investigations, with India and Korea following it in second and third place with 31 and 8 investigations against them, respectively. ${ }^{59}$

As of June 30, 2012 China has initiated as many as 195 antidumping investigations

53 See Diamond Sawblades and Parts Thereof from the People's Republic of China and the Republic of Korea: Antidumping Duty Orders, 74 (212) Fed. Reg. (Nov. 4, 2009); Certain Circular Welded Carbon Quality Steel Line Pipe from the Republic of Korea and the People's Republic of China: Initiation of Antidumping Duty Investigations, 73 (83) Fed. Reg. (Apr. 29, 2008); Coated Free Sheet Paper from China, Indonesia, and Korea, 71 (214) Fed. Reg. (Nov. 6, 2006).

54 Id.

55 Id.

56 Supra note 35.

57 WTO, Antidumping Measures by Exporting Country, available at http://www.wto.org/english/tratop_e/adp_e/AD_ MeasuresByExpCty.pdf (last visited on Mar. 1, 2013).

$58 \quad I d$.

59 WTO, Countervailing Measures by Exporting Country, available at $\mathrm{http} / /$ www.wto.org/english/tratop_e/scm_e/CV MeasuresByExpCty.pdf (last visited on Mar. 1, 2013). 
on its own against foreign exporters, placing Beijing in eighth place in the list of antidumping duty imposers. ${ }^{60}$ With respect to countervailing duty, China has initiated four investigations during the same period. ${ }^{61}$ While the number of investigations of the US is evenly spread out during this period, investigations by China are almost inclusively back-loaded, evidencing a more active approach adopted by China in recent years ${ }^{62}$.

The increase of China's own investigation in late 2000s can be interpreted as the country's realization of the importance of instituting 'retaliatory' or 'responsive' investigations against the United States. ${ }^{63}$ As a matter of fact, China is uniquely positioned in this regard. Unlike other developing countries, China possesses a sizable domestic market for exporters from other countries including the United States. A sizable domestic market is an essential element for 'retaliatory' or 'responsive' trade remedy investigations, because other countries are likely to be more cautious when it comes to conducting investigations and making determinations in these investigations fearing similar investigations and imposition against their own exporters. As both the US and China offer one of the largest exporting markets for other countries in the world, their tit-for-tat trade remedy investigations vis-à-vis other countries and against each other are largely expected. In light of this, one can assume that both countries will remain active users of trade remedy investigations at least for the time being.

In trade remedy investigations, domestic industries of these two countries employ a strategy in which they target not only exporters from the other country, but also those from third countries. This strategy is based upon consideration of legal requirements. For example, it becomes much easier to satisfy the so-called material injury standard, which is one of the mandatory requirements for imposing antidumping or countervailing duties. ${ }^{64}$ In terms of political aspects, inclusion of products and exporters of other countries in the mix of targets would help dilute the

60 Supra note 31.

61 Supra note 35.

62 During the period of 1995-2012, the United States and China initiated antidumping investigations against Korea 32 times and 31 times, placing the two countries in second place and third place respectively, after India in the first place with 49 times, in the list of countries that initiated antidumping investigations against Korean products. See supra note 31 .

63 USTR, 2010 National Trade Estimate Report on Foreign Trade Barriers (China Section), at 5, available at http:// www.ustr.gov/sites/default/files/uploads/reports/2010/NTE/2010_NTE_China_final.pdf (last visited on Mar. 1, 2013).

64 See Agreement on Implementation of Article VI of the General Agreement on Tariffs and Trade 1994 [hereinafter Antidumping Agreement] art. 3; Agreement on Subsidies and Countervailing Measures [hereinafter SCM Agreement] art. 15. In the case of the United States, see Tariff Act of 1930, as amended, at $\S 771$ (7) (A). 
nature of the US-specific or China-specific trade remedy investigations. ${ }^{65}$

It is even more alarming that the US and China are currently turning their focus from traditional antidumping duty investigations to countervailing ones. The United States, after long domestic controversies, has recently started to conduct countervailing duty investigations against China because, apparently, antidumping measures alone are not able to address the surge in Chinese products. ${ }^{66}$ Remarkably, China is also responding in kind by initiating its own countervailing duty investigations against the United States. ${ }^{67}$ Subsidy disputes also involve the domestic economic policies of other countries and thus carry a much wider impact than countervailing duty investigations. As many developing countries tend to possess governmentinitiated, export-oriented economic policies, the more active countervailing duty investigations of the US and China would be ominous for them. ${ }^{68}$

As such, exporting companies from other third countries, which probably would not be selected for investigations on their own, are now being included as sidekicks in two-way retaliatory investigations aimed at Chinese or the US companies to facilitate those investigations. By no means is this a good sign for the global trade regime. As bilateral trade disputes between the US and China continue to intensify and as more and more trade remedy investigations ensue, this phenomenon of "falling into the same trap" will increasingly manifest itself.

\section{Import Restriction Measures}

Being snared in this way is not necessarily confined to trade remedy investigations. The same rationale would apply to other trade measure with equal force. In fact, any US trade measure against China and any Chinese measure against the US outside the context of trade remedy investigations could be equally applicable to other countries with some modifications and adjustments. For instance, considering the

65 This is especially true in the case of Korea, which is a main exporter of almost all items destined for the US and China, and yet does not possess sizable domestic market to consider a counterweight trade remedy investigations in response to dubious trade remedy investigations. See P. Mozur, China to Probe U.S., South Korea Solar Products, WALL St. J., Jul. 20, 2012, available at http://online.wsj.com/article/SB100008723963904443309045775378209480 50662.html (last visited on Mar. 26, 2013).

66 US Dept. of Commerce, Press Release: Commerce Applies Anti-Subsidy Law to China, (Mar. 30, 2007), available at $\mathrm{http}: / / w w w . t r a d e . g o v / p r e s s / p r e s s \_r e l e a s e s . a s p$ (last visited on May 4, 2013).

67 Supra note 63, at 6.

68 E.g, Korea has been a perennial target of foreign subsidy investigations and has been involved a wide range of subsidy disputes due to its government-coordinated and export-oriented economic structure and policies. See D. Kirk, South Korea: U.S. To Investigate Chip Subsidies, N.Y. TIMES, Nov. 23, 2002, available at http://www.nytimes. com/2002/11/23/business/international-briefs-asia-south-korea-us-to-investigate-chip-subsidies.html (last visited on Mar. 26, 2013). 
US argument against China concerning the alleged currency manipulation and the US argument against Korea regarding Korea's regulation of its financial system, the Americans seem to call on a similar logic, i.e., allegedly illegitimate intervention by government in the financial market to sustain overall export performance. ${ }^{69}$ It is true that as each country's situation is different, each case requires a country-specific analysis.

A common underlying theme from the US position is, however, that governmentcoordinated, export-driven, domestic company-supporting economic policies could turn into trade measures in disguise, and thus should be regulated. ${ }^{70}$ Assuming that this US position materializes regarding the introduction of trade measures in the future (e.g., in the context of currency depreciation allegation), it seems likely that not only China but also other countries, such as Korea, could be implicated by the measures. This would also help dilute the China-specific nature of those prospective measures. The same situation could then arise with respect to Chinese trade measures against the US products.

\section{Manufacturing Facilities Re-Location Issue}

Products of other third countries could subsequently be implicated in the respective trade remedy investigations and other import restriction measures imposed by the US or China when the products are produced by manufacturing facilities in the two countries, but established by investments from those other countries. It is not uncommon that companies relocate their manufacturing facilities to China or establish new investments in China. Products manufactured by these facilities are of Chinese origin and can be encompassed by any US investigation against the product. ${ }^{71}$ The

69 H. Schneider, Obama Urged to Act on China's Currency Manipulation, WASH. Post, Mar. 26, 2010, available at http://www.washingtonpost.com/wp-dyn/content/article/2010/03/25/AR2010032503772.html (last visited on May 2, 2013). See also Staff Writer, USTR Takes Aim in Trade Barrier Reports, ReuTERS, Mar. 31, 2010, available at http://www.reuters.com/article/2010/03/31/us-trade-usa-china-idUSTRE62U4TQ20100331 (last visited on May 1, 2013). Cf. United States-Countervailing Duty Investigations on Dynamic Random Access Memory Semiconductors from Korea, WT/DS296/R (Feb. 21, 2005); Issues and Decision Memorandum for the Final Determination in the Countervailing Duty Investigation of Dynamic Random Access Memory Semiconductors from the Republic of Korea, 68 FR 37,122 (Jun. 23, 2003), comments 1, 2, 4 and 6.

70 For details on the Korea's argument, see United States-Countervailing Duty Investigations on Dynamic Random Access Memory Semiconductors from Korea, WT/DS296/R; Korea's argument in Issues and Decision Memorandum for the Final Determination in the Countervailing Duty Investigation of Dynamic Random Access Memory Semiconductors from the Republic of Korea, at comments 1, 2, 4 and 6; Initiation of Antidumping and Countervailing Duty Administrative Reviews and Request for Revocation in Part, 74 (182) Fed. Reg. 224 (Sept. 22, 2009).

71 Korea International Trade Association, LG's Air Conditioner from China Is Fearing Antidumping Investigations from the United States, Trade Remedy Information Database (Apr. 18, 2005). 
same situation also applies to the US products manufactured from the facilities established by investment from third countries. For instance, consider China's recent countervailing duty investigation against automobiles from the United States. If China expands its investigation or initiates a new investigation against automobiles from the US, and if automobile manufacturers of third countries whose manufacturing facilities are located in the United States (such as Hyundai or Toyota) start to export their products to China in the future, these US-manufactured automobiles will also become subject to the Chinese investigations.

As other countries' investment in the United States and China are expected to grow because of their economic vitality, any future trade friction between the two countries restricting importation of key manufactured goods stands to negatively affect the interest of companies and governments of third countries, as well. An argument can be made therefore that the intensification of trade friction between the two largest trading partners would hinder the globalized business operations of many corporations.

\section{B. Trapping Third Countries In-Between}

Another implication of the Sino-US trade disputes for other countries is that they tend to present third countries with dilemmas. While other countries are required to maintain and expand their trade with both the US and China, offering major export markets for them, the increasing confrontation between the two trade giants and the manifestation of different approaches to major trade issues make it more difficult for these third countries to align their policies with the basic approach taken by either of the two.

\section{Addressing Divergent Frameworks of FTAs}

A negative effect in this regard is the complications that other countries would experience as a result of the different approaches and models of the FTAs that the United States and China pursue, respectively. Escalating trade disputes between the United States and China have prompted the two countries to solidify their own FTA approaches and models to preserve their trade interests and to pursue creation of their own trade blocs. ${ }^{72}$ As other third countries pursue FTAs with the two countries, these discrepancies in basic frameworks of FTAs could complicate the third countries' coordination of domestic policies.

72 M. Greenberg, Time for a China-US Free Trade Agreement, WALL ST. J., Jan. 9, 2012, available at http://online.wsj. com/article/SB10001424052970203471004577143121577631562.html (last visited on Mar. 1, 2013). 
In the negotiating stage, China has a so-called "Early Harvest Program("EHP”)," which provides preferential benefits to the other treaty party even prior to the official signing of an FTA as an integral part of China's FTA strategy. ${ }^{73}$ When viewed from the US perspective of FTAs, however, this program may arguably constitute a violation of the relevant WTO rules - neither the enabling clause nor Article XXIV contemplates such an ad hoc application of an unconcluded FTA. After concluding FTAs with these two trade giants, other countries may thus find the different approaches and models of FTAs of the two countries posing challenges for their implementation of the agreements. This is particularly the case because other countries' implementation of the FTAs with these two countries has already become significantly complex due to the stringent and detailed requirements contained in the treaty text, which in turn is the reflection of the two countries' respective experience from the rise of bilateral trade disputes since $2006 .^{74}$

\section{Reconciling Policy Differences}

Increasingly, it is being observed that in a wide range of trade policies, the US and China seem to possess different views and distinct perspectives. The confrontation between the two trade giants put other trading partners, who have to maintain close trade relations with both countries, in a difficult position. Likewise, recent US-China disputes have also made other countries realize that a considerable discrepancy exists between the United States and China in their perceptions of some of the fundamental issues in the trade sector. This could also help these other countries prepare themselves to respond to their own disputes with the two trade giants. Although the contexts and backgrounds may differ considerably, some of the issues raised by the United States vis-à-vis China could apply to other with some modifications. For example, the recent extensive US search for China's subsidy programs in both its central and provincial governments could also function as a preemptive warning for other countries, which, to some extent, may implement

73 See Substantial Progress Made in Cross-Strait Economic Pact Talks, China Commodity net (Jun. 25, 2010), available at http://ccne.mofcom.gov.cn/bulletin/index.php?flag=4861 (last visited on Mar. 1, 2013). For information on the China-Taiwan EHP discussions and the China-ASEAN EHP Agreement, see Anne Tang, China, ASEAN to Strengthen Agricultural Cooperation, XINHUA News, Ост. 19, 2009, available at http://news.xinhuanet.com/english/2009-10/19/ content_12270645.htm (last visited on Mar. 1, 2013).

74 The complexity of the Chinese regulatory framework indeed poses a significant challenge for other countries. Thus, in China-Trading Rights, China claimed that the United States did not provide adequate and accurate factual information about its legislative framework and asked the WTO panel to dismiss the case. See Appellate Body Report, China Measures Affecting Trading Rights and Distribution Services for Certain Publications and Audiovisual Entertainment Products, WT/DS363/AB/R (Jan. 19, 2010) [hereinafter China-Trading Rights], at ๆๆ 165 \& 170, available at http:// www.wto.org/english/tratop_e/dispu_e/363abr_e.doc (last visited on Mar. 26, 2013). 
similar programs in various sectors.

China has been particularly critical of the WTO's possible infringement of its sovereignty. ${ }^{75}$ In China-Measures Affecting Trading Rights and Distribution Services case (DS363), China referred to the UNESCO Convention on the Protection and Promotion of the Diversity of Cultural Expressions, adopted in October 2005, to stress that cultural goods are different from other non-cultural goods and that the WTO Members maintain more leeway in regulating these goods. ${ }^{76}$ China pointed out that it could regulate foreign goods and services when it has legitimate concerns about preserving its cultural identity, ${ }^{77}$ an argument that was consequently rejected by the WTO's panel.

Another example of national sovereign infringement argument proffered by China has been taking place at the WTO dispute settlement proceedings in terms of the scope of the general exceptions stipulated in Article XX of the General Agreement on Tariffs and Trade 1994 (hereinafter GATT 1994). As is well known, an Article XX defense is considered to represent an important right of a WTO Member. In the China-Raw Materials case, China took the position that this exception should cover measures adopted to conserve exhaustible natural resources, ${ }^{78}$ and thus virtually any violation of substantive provisions of the GATT 1994 should be justified. In the dispute, China argued that it had adopted a multi-layered policy framework designed to meet a range of inter-related objectives regarding its sovereign natural resource endowments, which was virtually unreachable by WTO. ${ }^{79}$ The United States starkly opposed such an interpretation. ${ }^{80}$ The scope of Article XX defense is not entirely clear yet and is still subject to disputes between the US and China. ${ }^{81}$

Yet, another example concerns the subsidy disputes between the United States and China. The SCM Agreement does subject the WTO Members' provision of illegitimate subsidies to specific private economic entities within their territories to

75 Supra note 18, at 9 ๆ 7.499 - 7.501. China argued that the WTO panel should not illegitimately intrude into an issue that is reserved to the domestic jurisdiction, available at http://www.wto.org/english/tratop_e/dispu_e/362r_e.pdf (last visited on Mar. 26, 2013).

76 See WTO China-Measures Affecting Trading Rights and Distribution Services (DS363), available at http://www. wto.org/english/tratop_e/dispu_e/cases_e/ds363_e.htm (last visited on Mar. 26, 2013).

77 Id.

78 See Panel Report, China - Measures Related to the Exportation of Various Raw Materials, WT/DS394, 395, \& 398/R

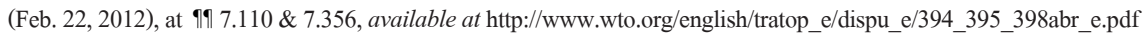
(last visited on Mar. 26, 2013).

79 Id. at 9 9 7.265, 7.365, 7.378-7.405.

$80 \quad$ Id. at 97.111 .

81 For details, see Appellate Body Report, United States - Standards for Reformulated and Conventional Gasoline, WT/ DS2/AB/R / DSR 1996: I, 3 (May 20, 1996), at 30. 
a rigorous discipline. In fact, the SCM Agreement does not provide for any special treatment or consideration with any particular type of governmental programs since the provisions stipulating the so-called 'non-actionable' subsidies lapsed on December 31, 1999. ${ }^{82}$ That means, however, that the SCM Agreement is also mindful not to interfere with the inherent authority of the Member governments to pursue legitimate public objectives and economic policies within the parameters of various provisions of the agreement. It is also summarized by the panel in Canada-Aircraft case. ${ }^{83}$ Almost all governments are actively involved in numerous projects to foster technological and scientific development of the academic institutions and industries within their territories. Thus, the line between a government's legitimate function and an illegal subsidization scheme through various governmental projects are sometimes not entirely clear. ${ }^{84}$ In fact, this very issue is being discussed in the course of the Doha Development Agenda negotiations. ${ }^{85}$

Viewing the fundamental differences in understanding key provisions of the WTO Agreements in these high profile disputes between the United States and China, some countries such as Korea clearly espouse the perspective held by the United States, which supports fuller promotion of private activity, further protection of private property rights, and more liberalization and deregulation of the market. ${ }^{86}$ Over time, these countries have made significant efforts to harmonize their perspectives and views with those of the United States in terms of economic regulation and policies. However, there are some economic or trade issues regarding which these same countries hold positions closer to China's perspectives, including the role of the government in regulating private activity in the market and the appropriateness of the government's intervention in the private sector. ${ }^{87}$ This

82 SCM Agreement art. 31.

83 See Panel Report, Canada - Measures Affecting the Export of Civilian Aircraft, WT/DS70/R (Aug. 20, 1999), at 99.119 .

84 SCM Agreement pt. IV \& art. 31.

85 See WTO Negotiating Group on Rules, Draft Consolidated Chair's Texts of AD and SCM Agreements, TN/RL/ W/213 (Nov. 30, 2007), SCM Agreement pt. IV.

86 In the case of Korea, such an effort originally started with the financial and regulatory reform following the 1997 financial crisis, and it has been further expedited during the course of the FTA negotiations with the United States. See Kihwan Kim, The 1997-98 Korean Financial Crisis: Causes, Policy Response, and Lessons, Presentation at a Seminar organized by IMF and Government of Singapore (Jul. 10-11, 2006), available at http://www.imf.org/ external/np/seminars/eng/2006/cpem/pdf/kihwan.pdf (last visited on Mar. 26, 2013).

87 See generally A. Inkeles, Continuity and Change: Popular Values on the Pacific Rim, 1 (1) StAn. J. Int'L Rel. (1998). With respect to the role of culture and societal traits in terms of trade disputes, see Panel Report, Japan-Measures Affecting Consumer Photographic and Paper, WT/DS44/R (Apr. 22, 1998) [hereinafter Japan-Film], at १ף

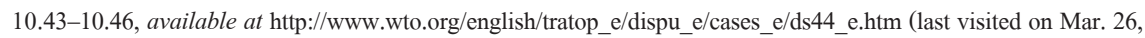
2013). 
does not mean that individual countries support China in specific disputes involving such issues; in fact, developing countries may well have views different from China. Instead, it simply means that, irrespective of the possible violation of international trade agreements in technical terms, an argument can be made that other countries may at least understand the basic rationale of China in introducing certain economic or trade measures.

The role of the government in regulating the private market continues to flare up in the context of China's State-Owned Enterprises ("SOEs"), which account for almost half of China's GDP according to some recent statistics. The question then is how these unique enterprises should be treated in terms of treaty application and implementation. ${ }^{88}$ Particularly vigilant here is the United States who makes this issue one of the top priorities in its negotiations of various agreements including TPP that may have relevance to China. During the WTO's Trade Policy Review of China conducted in August 2012 at WTO, questions concerning the SOEs took center stage. $^{89}$

In this respect, it should be noted that the International Law Commission itself has recognized that this kind of inquiry involves cultural background discussions and contextual analyses. ${ }^{90}$ In fact, the ILC Commentary on this issue states that: "Article 5 [of the 2001 Draft Articles] does not attempt to identify precisely the scope of 'governmental authority' for the purpose of attributing the conduct of an entity to the State." 91 The ILC Commentary further elaborates that: "What is regarded as 'governmental' depends on the particular society, its history and traditions." 92 Thus, it denounces any categorical approach, but places emphasis on the specific factual circumstances of the case, including cultural or societal background.

Other countries' positions in these intense US-China disputes are necessarily nuanced. In relation to some issues, in particular, the developing countries seem to share the US position when the issues relate to further opening the market of China. But for others the developing countries seem to side with the Chinese approach to the extent the preservation of national sovereignty is concerned. The developing

88 Draft Articles on Responsibility of States for Internationally Wrongful Acts arts. 5 \& 8. U.N. GAOR, 56th Sess., Supp. No. 10, U.N. Doc. A/56/10 (Dec. 6, 2001), ch. IV.E.1. For details, see The Commentary to the 2001 ILC Draft Articles, available at http://untreaty.un.org/ilc/texts/instruments/english/commentaries/9_6_2001.pdf (last visited on Mar. 1, 2013).

89 WTO, Trade Policy Review: China, summarizing the fourth review of China's trade policies and practices, available at http://www.wto.org/english/tratop_e/tpr_e/tp364_e.htm (last visited on Mar. 26, 2013).

90 ILC Commentary, supra note 88 , at 43.

91 D. Bodansky \& J. Crook, Symposium: The ILC's State Responsibility Articles, Am. J. InTL. L. $773-789$ (2002).

92 ILC Commentary, supra note 88 , at 43. 
world is therefore meticulously eyeing the current surge of trade friction between the two trade giants. The situation of Korea offers an example in this regard. For a long time, foreign governments have claimed that the government of Korea is managing the Korean financial market to the benefit of its companies. ${ }^{93}$ This regulation of the financial market has been a constant source of concern on the part of foreign countries, particularly Western entities such as the US and the EU. ${ }^{94}$ In their view, the government of Korea is orchestrating the financial market for the purpose of artificially inflating the competitiveness of Korean companies while disadvantaging foreign companies. Korea has countered that it is simply adopting and implementing legitimate governmental policies, as does any other government. ${ }^{95}$ These interactions between Korea and other countries resemble those between China and the United States.

As such, US-China disputes present instances in which other countries realize the existence of a mismatch between the different perspectives regarding the same issue. Because the WTO norms are not sufficient and detailed enough, disputes between major trading partners (e.g., China and the United States) addressing the WTO norms regarding new issues (such as trade and environment, trade and security, trade and financial sovereignty, and trade and culture) are bound to intensify; the losing party will do whatever it takes to reject a ruling or to find an excuse to delay implementation of the ruling. Sharp confrontations between the US and China will continue to test these perspective-related trade issues. Other third countries' position in the midst of fierce confrontation will be likely to remain precarious.

\section{Stimulating Protectionist Tendencies}

Watching the surge of Sino-US bilateral trade disputes where the two leading countries employ a plethora of governmental measures to protect their domestic industries, governmental agencies of other countries would be tempted to consider adopting similar policies to protect and support their domestic industries and companies. ${ }^{96}$ In fact, the Sino-US disputes are already said to have prompted

93 See Panel Report, United States-Countervailing Duty Investigations on Dynamic Random Access Memory Semiconductors from Korea, WT/DS296/R (Feb. 21, 2005) [hereinafter US-DRAMs], at 19 7.6-7.8, 7.49-7.50, 7.59; Panel Report, European Communities-Countervailing Measures on Dynamic Random Access Memory Chips from Korea, WT/DS299/R (Jun. 17, 2005) [hereinafter EC-DRAM], at १९ 7.38-7.46.

94 Id.

95 S. Mundy \& Yeonsoo Chung, S Korea Set to Overhaul Key Lending Rate, Financial Times, Aug. 8, 2012, available at http://www.ft.com/intl/cms/s/0/3e0da92a-d62c-11e1-b547-00144feabdc0.html\#axzz2Oeqr5f7X (last visited on Mar. 26, 2013).

96 Ui-dal Song, Korea Is Lagging Behind in Electricity Car (꼴찌가 보이는 한국 전기차), CHosun DAILy, Jun. 
some of the companies of other countries to request that their governments adopt policies to support domestic industries. In other words, to the extent that Sino-US trade disputes reveal the various protectionist measures of the two trade giants who are supposed to show global leadership in this field, the domestic pressure in other countries to introduce similar measures to help their companies maintain their competitive edge has mounted. This could easily develop into a situation in which other trading partners claim that their counterparts implement illegitimate protectionist measures, which may then lead to the a chain-reaction trade disputes between and among other countries. ${ }^{97}$

\section{Turning the Challenges into a New Opportunity}

As explained above, the Sino-US disputes have implications in many different dimensions. They are not merely about the trade tension between the two trading giants, but instead carry systemic implications for other countries and the global trading regime. At its core, the continuing disputes stand to further complicate other countries' position in trade issues, and thus create an environment for more disputes globally. Considering the current circumstances, at least for the time being, it seems unlikely that the US and China will be able to find common ground in the trade sector and avoid bilateral disputes which are deeply rooted in the differences in perspectives. Under these circumstances, the negative implications would continue to pose significant challenges for other countries. It does not seem likely that other countries can easily break themselves from this dilemmatic situation. ${ }^{98}$

At the same time, there are silver linings that are apparent from this challenge. The bilateral trade tension and ensuing disputes could also operate as an important

13, 2010, available at $\mathrm{http}: / /$ srchdb1.chosun.com/pdf/i_service/pdf_ReadBody.jsp? $\mathrm{Y}=2010 \& \mathrm{M}=06 \& \mathrm{D}=14 \&$ $\mathrm{ID}=2010061400077$ (last visited on Mar. 26, 2013). See also Staff Writer, S. Korea Unveils a Plan to Boost Auto Industry, Hankyoreh Daily, Mar., 27, 2009, available at http://english.hani.co.kr/arti/english_edition/e_ business/346508.html (last visited on Mar. 26, 2013).

97 K. Bradsher, China-U.S. Trade Dispute Has Broad Implications, N.Y. TımEs, Sept. 14, 2009, available at http:// www.nytimes.com/2009/09/15/business/global/15trade.html?pagewanted=all\&_r=0 (last visited on March 26, 2013).

98 As for China's strategy to vigorously expand its bilateral and regional FTA networks, while showing unique characteristics in its FTAs, see C. Barfield, The Dragon Stirs: China's Trade Policy for Asia - and the World, 24 Ariz. J. Int'L \& Comp. L. 109-111 (2007); Si-soo Park, Korea-China FTA Negotiations Hit Snag, The Korea Times, Jul. 6, 2012. The surge of FTAs on the one hand, and the fundamental differences in FTAs concluded by the US and by China on the other put countries like Korea in a dilemmatic position, when they try to conclude FTAs with these two countries. 
turning point for the global trading regime. First, these disputes could contribute to enhance the rule of law by offering various instances of treaty interpretation covering controversial disputes. Second, the Sino-US trade disputes could also offer opportunities for the international community to form consensus on newly emerging issues. In order for these positive aspects not to be outweighed by the negative aspects set forth above, collective efforts by the global community are certainly necessary. ${ }^{99}$

\section{A. Enhancing "Rule of Law" in Global Trade}

The recent disputes between the United States and China have posed many notable issues with respect to the interpretation of the WTO Agreements. The bilateral disputes have not just increased in number, but also raised legal issues that have not been fully addressed by the WTO panels and the Appellate Body before. The following are a few examples in this regards: (1) the export restriction for raw materials; (2) invocation of general exceptions; (3) governmental intervention in the financial market; and (4) governmental subsidies to achieve green growth and carbon reduction. Laws and regulations of the two countries are carefully scrutinized and examined. ${ }^{100}$ These questions are already contained and regulated by the covered agreements of WTO to some extent, but more clarification and elaboration are indeed necessary to address newly emerging issues in the global community.

A recent dispute between the US and China has offered a timely opportunity to discuss the issue of when a private action rises to the level of governmental action. In US-AD/CVD case, a dispute brought by China against the United States regarding the latter's double investigations and imposition of antidumping duties and countervailing duties against the former, the WTO's Appellate Body had an occasion to elaborate the principles of public international law relating to attribution of private action to its government. In the dispute, the Appellate Body overturned the decision of the panel that followed the previous WTO jurisprudence in which the governmental ownership had been regarded as a decisive factor. ${ }^{101}$

99 C. Isidore, U.S. vs. China: The Trade Battles, CNN Money, Mar. 13, 2012, available at http://money.cnn. com/2012/03/13/news/international/china-trade/index.htm (last visited on Mar. 26, 2013).

100 See Appellate Body Report, United States - Measure Affecting Imports of Woven Wool Shirts and Blouses from India, WT/DS33/AB/R (Apr. 25, 1997), at 14; Appellate Body Report, European Communities-Conditions for the Granting of Tariff Preferences to Developing Countries, WT/DS246/AB/R (Apr. 20, 2004), at 33, ๆ 87.

101 See Panel Report, United States - Definitive Anti-Dumping and Countervailing Duties on Certain Products from China, WT/DS379/R (Mar. 25, 2011) [hereinafter US-AD/CVD (Panel)], ๆๆ 320-322, available at http://www.wto. org/english/tratop_e/dispu_e/379r_e.doc (last visited on Mar. 26, 2013). 
Thus, the Appellate Body in this dispute offered new jurisprudence in determining when an action adopted by an entity in which a government maintains shareholding becomes and an action by the government itself. ${ }^{102}$ It criticized prior jurisprudence and analyses of the underlying panel in the dispute. ${ }^{103}$ The Appellate Body held that: "Just as no two governments are exactly alike, the precise contours and characteristics of a public body are bound to differ from entity to entity, State to State, and case to case." ${ }^{104}$ This stance of the highest court of the world trade disputes represents a significant development of jurisprudence in WTO - largely in the right direction and in compliance with the jurisprudence pronounced in the ILC Draft Articles and its Commentary. ${ }^{105}$ Although some questions still remain, ${ }^{106}$ this can be definitely regarded as a major clarification and elaboration of jurisprudence.

In addition, this jurisprudence of the Appellate Body in US-AD/CVD could also apply to other covered agreements. For instance, an inquiry as to when a governmental purchase of goods and services takes place for the purpose of the application of the Agreement on Government Procurement (“GPA”) also requires a determination of who the governmental entities are in the first place. ${ }^{107}$ An inquiry as to the definition of 'public entity' in the General Agreement on Trade in Services ("GATS") is another example of the application of the clarified jurisprudence. ${ }^{108}$

This example evidences that when properly managed by the dispute settlement mechanism, the Sino-US disputes could offer a new momentum and opportunity to resolve controversial issues in the international community. The outcome of these disputes may offer jurisprudence for the settlement of controversial disputes for other countries. Other countries may get policy guidance from these disputes, as well. This will help enhance rule of law in the global trade regime. The success of this possibility depends upon an effectively operating and trust producing dispute settlement mechanism. This observation in turn underscores the currently on-going negotiations to amend the Understanding on Rules and Procedures Governing the Settlement of Dispute ("DSU") so as to enhance due process and the effectiveness of the remedy in the WTO's dispute settlement mechanism.

102 Id. at 9347.

103 Supra note 101, ๆ 8.134; US-AD/CVD (AB), supra note 42, at 9310.

104 Id.

105 the ILC Commentary, supra note 88, at 38-43 (discussing case law when state action can be found for the purpose of ascertaining State responsibility) \& 47-49 (discussing case law relating to when private action rises to the level of state action so that it can be attributed to a State).

106 Supra note 42, ๆๆ 310,349-350 \& 355.

107 GPA art. 1(1).

108 GATS Annex on Financial Services 9 5(c). 


\section{B. Reshaping the Common Ground for New Trade Issues}

A few new trade issues are not yet addressed by the existing trade agreements. Accordingly, consensus among States for a future direction has not been formed. If the above clarification concerns those issues that are already contained in the covered agreements of WTO one way or another, these issues without consensus relate to issues that have been traditionally discussed in other international fora and documents. However, they would be dragged into the trade agreements' jurisdiction due to the impact on trade. The issues that extend beyond the purview of the WTO Agreements or that concern other international agreements are not covered by the jurisdiction of the WTO's dispute settlement proceeding. ${ }^{109}$ In fact, Article 3.2 of DSU provides that: "Recommendations and rulings of the DSB cannot add to or diminish the rights and obligations provided in the covered agreements." Article 19.2 of DSU also has a similar provision, so there is a clear hindrance in dealing with new trade issues under the existing framework of the WTO Agreements.

For better or worse, the Sino-US disputes offer an opportunity to deal with new issues. Subsidization for renewable energy is one example. On the one hand, governmental support for private entities for whatever purpose is proscribed by the GATT 1994 and the SCM Agreement. ${ }^{110}$ On the other, the international community has committed itself to the attainment of green growth mandating respective governments to consider various support measures. ${ }^{111}$ A similar situation is also observed with respect to the currency policies that many governments have adopted. While providing financial support is proscribed by GATT and the SCM Agreement even if such support takes place in the form of a monetary policy or foreign exchange policy, the arrangement with the IMF, constituting yet another international legal instrument, may still require and permit such a policy. Protection of cultural identity in the trade liberalization context is another example of such divided legal orientation. ${ }^{112}$ Governments are torn between the two different international legal norms in these situations. These differences can be sorted out and ultimately harmonized, so that the WTO Members can expect consistent norms in order to achieve the basic objective of the Article 3.2 of DSU.

109 See Understanding on Rules and Procedures Governing the Settlement of Disputes arts. 3(2) \& 19(2), Apr. 15, 1994; Marrakesh Agreement Establishing the World Trade Organization, Annex 2, 1869 U.N.T.S. 401.

110 SCM Agreement arts. 1 \& 2 .

111 Request for Consultations by China, United States-Countervailing Duty Measures on Certain Products from China, (WT/DS437/1) (G/L/988) (G/SCM/D90/1) (May 30, 2012), at 8. The green growth issue remains at the top of the agenda of the G-20 meeting. See The White House Office of the Press Secretary, G-20 Leaders Declaration, available at http://www.whitehouse.gov/the-press-office/2012/06/19/g20-leaders-declaration (last visited on Mar. 1, 2013).

112 Supra note 74 , at 925. 
The Sino-US disputes may be used as a platform to address these issues through WTO negotiations or other international venues. Within WTO, multilateral negotiations such as DDA or post-DDA may address these issues. Other international fora, such as G-20 summit meeting, may address these issues outside the WTO context. The Sino-US disputes showcase important issues to be dealt with in these negotiation settings and the juxtaposed views on such issues.

\section{Conclusion: For Constructive Management of the Sino-US Trade Disputes}

The US and China are engaged in a range of high-profile trade disputes. As it currently stands, the bilateral trade disputes between the two countries will continue to intensify for the time being. If the TPP - apparently one of the policy priorities of the US in the trade sector - emerges in the Pacific basin region, e.g., China might even try to form a similar bloc of its own. China's effort to conclude an FTA with Korea and possibly with Japan indicates its long-term plan to establish a trade bloc of its own so that it can counter the trade bloc initiated by the United States in this region.

The Sino-US disputes force these other countries to strategically encounter new problems at a time of changing global trade paradigms. As the United States and China try to expand their webs of FTAs with their trading partners, these partners are also entangled with US-China confrontations one way or another. As much as these trading partners pursue further economic integration with the United States and China, though to varying extents, through their respective FTAs with the two countries, they are also exposed to the increasing intensity of the bilateral trade disputes between the two trade giants. Korea offers a good example. As Korea has already concluded an FTA with the United States and is in the process of negotiating with China, it is expected to have one in a couple of years.

At the same time, the surge of trade remedy investigations and import restriction measures introduced by Washington and Beijing as tit-for-tat acts has an effect of implicating exporters from other third countries. Legal requirements of trade agreements incentivize bringing exporters from other countries within the ambit of trade remedy investigation or import restriction measures. The Sino-US trade disputes are not merely confined to bilateral framework. Due to the two countries' vast influence in the global trade and the recent rapid emergence of trade blocs, the bilateral disputes between the US and China also carry the potential of putting 
other countries in more precarious positions. The Sino-US bilateral disputes thus carry wider, systemic implications for virtually all WTO Members since the claims presented in these disputes touch upon some of the core elements of the WTO Agreements.

As a consequence, the international community should be adequately apprised of this aspect of Sino-US disputes. It should also explore ways to utilize the disputes as a means of addressing global trade issues in a constructive manner. Strategically guided and properly managed, the controversial bilateral disputes may in fact turn into a new platform for identifying loopholes and ultimately finding solutions to difficult questions. 
